\title{
A Case Report of WEBINO Syndrome with Convergence Impairment
}

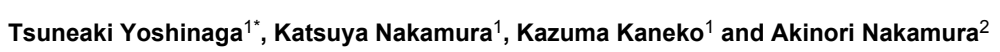

${ }^{1}$ Department of Neurology, Suwa Red Cross Hospital, 5-11-50 Kogandori, Suwa 392-8510, Japan

2Intractable Disease Care Center, Shinshu University Hospital, 3-1-1 Asahi, Matsumoto 390-8621, Japan

*Corresponding author: Tsuneaki Yoshinaga, Department of Neurology and Rheumatology, Shinshu University Hospital, 3-1-1 Asahi Matsumoto 390-8621, Japan, Tel: +81-263-37-2673; Fax: +81-263-37-2427; E-mail: kiccho@shinshu-u.ac.jp

Received date: Dec 08, 2014, Accepted date: Feb 17, 2015, Published date: Feb 24, 2015

Copyright: (c) 2015 Yoshinaga T, et al. This is an open-access article distributed under the terms of the Creative Commons Attribution License, which permits unrestricted use, distribution, and reproduction in any medium, provided the original author and source are credited.

Abstract
A 73-year-old man suddenly presented with alternating exotropia, bilateral medial longitudinal fasciculus (MLF)
syndrome, and impaired convergence. This symptom has been known as wall-eyed bilateral internuclear
ophthalmoplegia (WEBINO syndrome). Diffusion-weighted images on magnetic resonance imaging showed a small-
localized lesion in his pontine tegmentum. Based on he had some ischemic risk factors; he was diagnosed as having
an ischemic stroke and started an antiplatelet therapy. His convergence impairment was improved, but abduction
impairment of the right eye remained even 3 months later.
The causing lesion of WEBINO syndrome has been reported to be either midbrain or pons mainly due to ischemic
strokes or demyelinating diseases. In some cases, this syndrome was accompanied by convergence impairment;
however, the pathophysiologic mechanism has not yet been elucidated. The neural circuit of vergence is discharges
to the medial rectus subnucleus located in the abducens nerve nucleus. The mesencephalic reticular formation and
nucleus reticularis tegmenti pontis (NRTP) are important regions in making signals of the supranuclear pathway, and
NRTP impairment can induce the slow and fast vergence impairment. Thus, an involvement of near region of NRTP
might be associated with WEBINO syndrome with convergence impairment.

\section{Keyword:}

WEBINO (Wall-eyed bilateral internuclear ophthalmoplegia) syndrome; Alternating exotropia; Cerebral infarction; Multiple sclerosis

\section{Introduction}

Wall-eyed bilateral internuclear ophthalmoplegia (WEBINO syndrome) represents a bilateral adduction deficit of the eyes with exotropia, and was firstly reported in 1974 [1]. Most cases are caused by multiple sclerosis or ischemic stroke. Lesions of the mesencephalic or pontine tegmentum have been considered as the responsible for WEBINO syndrome. Another report described a patient with progressive subnuclear palsy with WEBINO syndrome, suggesting that neurodegenerative diseases may cause this syndrome [2].

We report herein the case of a patient with WEBINO syndrome and convergence impairment due to a small lesion of the pontine tegmentum caused by an ischemic stroke.

\section{Case}

The patient was a 73-year-old man who experienced sudden onset of diplopia. Two days later, diplopia remained unimproved and he visited a nearby hospital. However, the cause of symptoms was unclear, and he was transferred to our hospital for further examination. The patient's consciousness was alert, blood pressure was $151 / 83 \mathrm{mmHg}$, heart rate was 68 beats/min with a regular sinus rhythm, and his temperature was $35.8^{\circ} \mathrm{C}$. Vascular risks were old age and hypertension. His both pupils were isocoric and round, and pupil diameter was $3 \mathrm{~mm}$ in the room light. Direct and indirect pupillary light reflexes in his both eyes were brisk. Visual field defects were not observed. In his primary gaze position, he showed bilateral exotropia that was stronger on the left than the right (Figure 1A). Neither ptosis nor nystagmus was detected. His convergence was impaired, and the eye on each side was abducted fully on lateral gaze of the same side, while the contralateral eye failed to adduct. Testing of other cranial nerves yielded normal results. His motor function, coordination, and sensory and autonomic nervous systems were not involved.

A

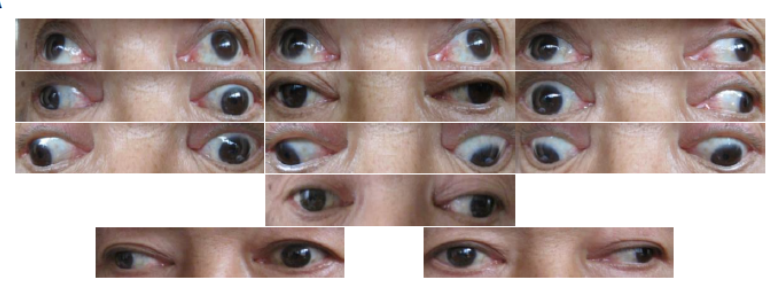

Figure 1: A) Pictures of ocular movements of the patient on the first hospital day. Extropia of either eye in the front position and adduction deficit of either eye on lateral gazing were observed. His convergence was also impaired. Alternating exotropia, with the right eye fixed, the left eye was deviated outward. Being instructed to use the left eye for fixation, the right eye was deviated outward.

The peripheral blood examination showed that blood cell count was within normal level; hemoglobin A1c, 5.4\%; blood glucose, $172 \mathrm{mg} / \mathrm{dl}$; and normal results for C-reactive protein level, thyroid hormone level and coagulation testing. Negative results were obtained for anti-CL/ 
ß2GPI antibody, anti-cardiolipin-immunoglobulin (Ig) G antibody, lupus anticoagulant, antinuclear antibody, anti-neutrophil cytoplasmic autoantibody, and anti-acetylcholine receptor antibody. The edrophonium test was also negative. The cerebrospinal fluid examination indicated a normal cell count (monocytes $3 / 3$ ), total protein at $20 \mathrm{mg} / \mathrm{dl}$, immunoglobulin $\mathrm{G}$ at $1.0 \mathrm{mg} / \mathrm{dl}$, and no oligoclonal band and myelin basic protein. Ophthalmological studies revealed no abnormalities of the optic nerve and papilla; central flicker value showed no significant difference between left and right. Brain magnetic resonance imaging (MRI) revealed a small lesion in the pontine tegmentum with a faint signal hyper-intensity on diffusionweighted imaging (Figure 1B) and a low value on apparent diffusion coefficient (ADC) mapping. Fluid-attenuated inversion recovery (FLAIR) MRI showed several small lesions scattered on the white matter. Brain MRI angiography showed no stenosis in the main trunk arteries.

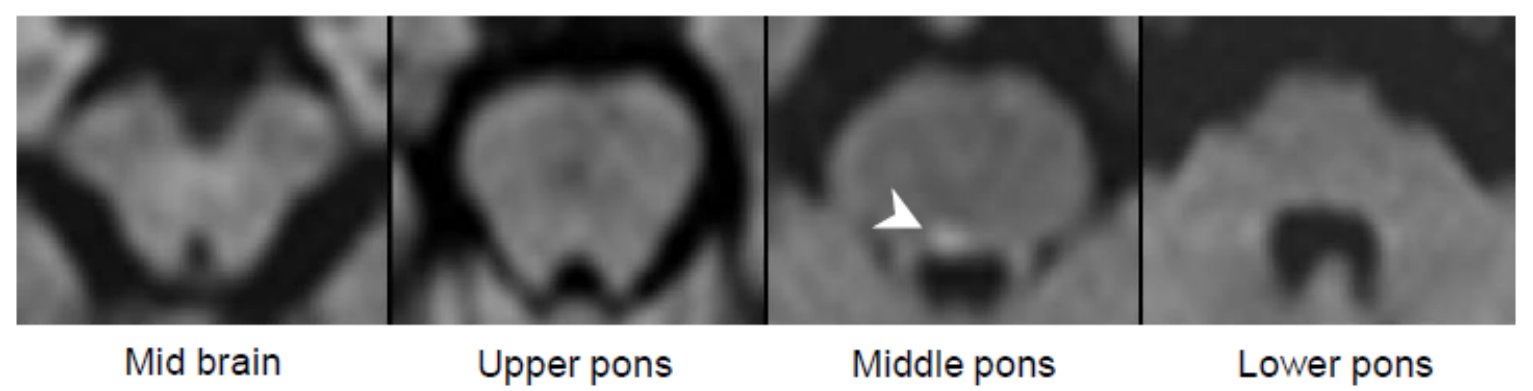

Figure 1: B) FLAIR imagings of the brainstem MRI on the third hospital day. The arrow showed a small, hyper-intense region on the right side of pontine tegmentum. Other images of midbrain and another section of pontine show no abnormalities.

Based on the presence of vascular risk factors, and given the acute onset, pontine infarction was likely to his diagnosis. He was administered ozagrel sodium at $160 \mathrm{mg} /$ day and edaravone at 60 $\mathrm{mg} /$ day as anti-platelet therapies. After administering the antiplatelet drugs, we started oral cilostazol at $200 \mathrm{mg} /$ day to prevent the recurrence. Ten days after the onset, FLAIR imaging of the brain revealed the lesion limited to the pontine tegmentum (data not shown). Eye symptoms did not improve, but activities of his daily living were sufficient for independence, and he was discharged on hospital day 11. At day 84 after first visiting the hospital, the convergence impairment was improved although residual abduction impairment of the right eye remained (data not shown).

\section{Discussion}

Fourteen cases of WEBINO syndrome with a brainstem lesion were reported from 1984 to 2013. In those cases, the causative lesions were in the tegmentum of pons, pons-midbrain, or midbrain, and this syndrome is known to be caused by various underlying diseases (Table 1) $[2-12]$.

In WEBINO syndrome, exotropia is a distinct sign. Stimulation of bilateral paramedian pontine reticular formations (PPRFs) is usually transmitted to bilateral extraocular muscles, but inadequately to bilateral intraocular muscles due to dysfunction of the medial longitudinal fasciculus (MLF), resulting in bilateral exotropia. Fixing one eye stimulates the contralateral PPRF, inducing adduction of one eye, resulting in enhancement of exotropia. Considering the abduction of the left eye on primary gaze compared to the right eye in our case, ocular involvement might have been associated with the right-side lesion of the pontine tegmentum.

On the other hand, bilateral internuclear opthalmoplegia (bilateral INO) is on condition that paralysis of adduction in the ipsilateral eye for all conjugate eye movements usually (but not always) with preservation of convergence, and horizontal nystagmus in the contralateral eye when this eye is in abduction. The difference between
WEBINO and bilateral INO is a bilateral primary gaze position, exotropia, and a convergence impairment seen in most cases. WEBINO syndrome is caused by bilateral MLF and medial rectus subnuclei lesions, the lesion at midbrain, especially bilateral lesion to the medial rectus subnuclei is the most defended hypothesis; however, other candidate lesions have been reported, and the brainstem lesion involved in the pathophysiology of this syndrome are still in controversy. On the other hand, bilateral ILO is caused by bilateral lesion of MLF.

Our patient also showed a convergence impairment, which often accompanies WEBINO syndrome. Convergence represents the voluntary movement of the eyes in different directions, and is brought into an action when looking at a near object. The eyes turn inward and at the same time the lens allows near vision. Divergence is required for distant vision. Vergence is also separated by speed into slow and fast. Slow vergence is brought about when the object approaches the eyes slowly, while fast vergence occurs when looking alternately between near and distant objects. The neural circuit of vergence definitively discharges to the medial rectus subnucleus (MRSN) located in the abducens nerve nucleus. The mesencephalic reticular formation (MRF) and nucleus reticularis tegmenti pontis (NRTP) are important in making signals of the supranuclear pathway. Some neurons have been identified as providing signals of the horizontal saccadic vergence as well as PPRF for vertical saccade. Vergence-related neurons are close to other neurons in the NRTP, which is related to both signals of saccade-vergence and saccade-pursuit. Actually, an impairment of the NRTP caused slow and fast vergence [13].

Four cases of WEBINO syndrome with only pontine lesion have been reported (Table 1). Among them, the convergence impairment was observed in one case [8]. In case No. 7 having pontine tegmentum lesion with convergence impairment in Table 1, the MRI showed a small and slightly left deviated lesion of the pons. In contrast, the pontine lesion of our case was right deviated. In other two patients having pontine tegmentum lesion (case No. 2 and No. 3 in Table 1) did not show the convergence impairment, and their MRI revealed a 
broader and symmetric lesion. We are not able to refer the relationship between the size of lesion and the presence or absence of convergence impairment. However, small and asymmetric pontine tegmentum lesion may be associated with the convergence impairment, although the size of the observation sample was one of the limitations.

\begin{tabular}{|c|c|c|c|c|c|c|c|}
\hline $\begin{array}{l}\text { Cas } \\
\text { e }\end{array}$ & $\begin{array}{l}\mathrm{Ag} \\
\mathrm{e}\end{array}$ & $\begin{array}{l}\text { Se } \\
x\end{array}$ & Cause & Focus & $\begin{array}{l}\text { Convergen } \\
\text { ce } \\
\text { impairment }\end{array}$ & \begin{tabular}{|l} 
Other \\
neurological \\
symptoms
\end{tabular} & Ref \\
\hline 1 & 72 & $M$ & $\begin{array}{l}\text { Progressive } \\
\text { supranuclear } \\
\text { palsy }\end{array}$ & $\begin{array}{l}\text { Midbrai } \\
\mathrm{n}\end{array}$ & + & $\begin{array}{l}\text { Upward gaze } \\
\text { palsy }\end{array}$ & 2 \\
\hline 2 & 49 & $M$ & $\mathrm{Cl}$ & Pons & - & None & 3 \\
\hline 3 & 50 & $M$ & $\begin{array}{l}\text { Multiple } \\
\text { sclerosis }\end{array}$ & Pons & - & $\begin{array}{l}\text { Upward } \\
\text { nystagmus }\end{array}$ & 4 \\
\hline \multirow{2}{*}{4} & \multirow{2}{*}{33} & \multirow{2}{*}{$\mathrm{M}$} & \multirow{2}{*}{$\begin{array}{l}\text { Central } \\
\text { nervous } \\
\text { system } \\
\text { cryptococcosi } \\
\mathrm{s}\end{array}$} & \multirow{2}{*}{$\begin{array}{l}\text { Midbrai } \\
\mathrm{n}\end{array}$} & \multirow{2}{*}{+} & $\begin{array}{l}\text { Skew } \\
\text { deviation, }\end{array}$ & \multirow{2}{*}{5} \\
\hline & & & & & & $\begin{array}{l}\text { upward gaze } \\
\text { palsy }\end{array}$ & \\
\hline 5 & 24 & $F$ & $\begin{array}{l}\text { Tuberculosis } \\
\text { granuloma }\end{array}$ & $\begin{array}{l}\text { Midbrai } \\
\mathrm{n}\end{array}$ & + & None & 6 \\
\hline 6 & 20 & $\mathrm{~F}$ & $\begin{array}{l}\text { Postsurgical } \\
\text { hematoma }\end{array}$ & $\begin{array}{l}\text { Pons- } \\
\text { midbrai } \\
n\end{array}$ & + & $\begin{array}{l}\text { Rt. hemiplegia, } \\
\text { Lt. tongue } \\
\text { deviation, } \\
\text { facial palsy }\end{array}$ & 7 \\
\hline 7 & 64 & $M$ & $\mathrm{Cl}$ & Pons & + & n.d. & 8 \\
\hline 8 & 78 & $M$ & $\mathrm{Cl}$ & $\begin{array}{l}\text { Mid } \\
\text { brain }\end{array}$ & + & $\begin{array}{l}\text { Upward gaze } \\
\text { palsy, upward } \\
\text { nystagmus }\end{array}$ & 9 \\
\hline 9 & 55 & $M$ & $\begin{array}{l}\mathrm{Cl} \text { (top of } \\
\text { basilar) }\end{array}$ & $\begin{array}{l}\text { Mid } \\
\text { brain- } \\
\text { thalamu } \\
\text { s }\end{array}$ & + & $\begin{array}{l}\text { Mydriasis, } \\
\text { ophthalmoplegi } \\
\text { a palsy }\end{array}$ & 10 \\
\hline 10 & 19 & $\mathrm{~F}$ & $\begin{array}{l}\text { NMO } \\
\text { spectrum } \\
\text { disorders }\end{array}$ & $\begin{array}{l}\text { Pons- } \\
\text { midbrai } \\
\mathrm{n}\end{array}$ & - & $\begin{array}{l}\text { Rt. tongue } \\
\text { deviation, } \\
\text { Lhermitte sign } \\
(+)\end{array}$ & 11 \\
\hline 11 & 66 & $M$ & $\mathrm{Cl}$ & $\begin{array}{l}\text { Midbrai } \\
\mathrm{n}\end{array}$ & - & None & 12 \\
\hline 12 & 84 & $M$ & $\mathrm{Cl}$ & $\begin{array}{l}\text { Pons- } \\
\text { midbrai } \\
\mathrm{n}\end{array}$ & - & $\begin{array}{l}\text { Upward gaze } \\
\text { palsy }\end{array}$ & 12 \\
\hline 13 & 65 & $\mathrm{~F}$ & $\mathrm{Cl}$ & $\begin{array}{l}\text { Pons- } \\
\text { midbrai } \\
\mathrm{n}\end{array}$ & + & None & 12 \\
\hline 14 & 73 & $M$ & $\mathrm{Cl}$ & Pons & + & None & $\begin{array}{l}\text { Our } \\
\text { cas } \\
\text { e }\end{array}$ \\
\hline
\end{tabular}

Table 1: The literature for WEBINO syndrome; M, male; F, female; CI, cerebral infarction; CIDP, chronic inflammatory demyelinating polyneuropathy; NMO, neuromyelitis optica; n.d., not determined

We considered that the mechanism of convergence impairment with a pontine lesion involves a supranuclear lesion of NRTP (Figure 1C) $[14,15]$. Garcia and Eqido described the pontine lesion as causing impairment of vergence and disagreed with the involvement of NRTP as the pathology [16]. However, our patient showed a pontine lesion near NRTP, suggesting that the mechanism of convergence impairment in WEBINO syndrome might be related to NRTP region. A new neuroradiological approach such as functional MRI or positron-emission tomography might be non-invasively available to reveal the mechanism in future. Moreover, accumulation of further cases is also needed to clarify the relationship between the mechanism of convergence and NRTP.

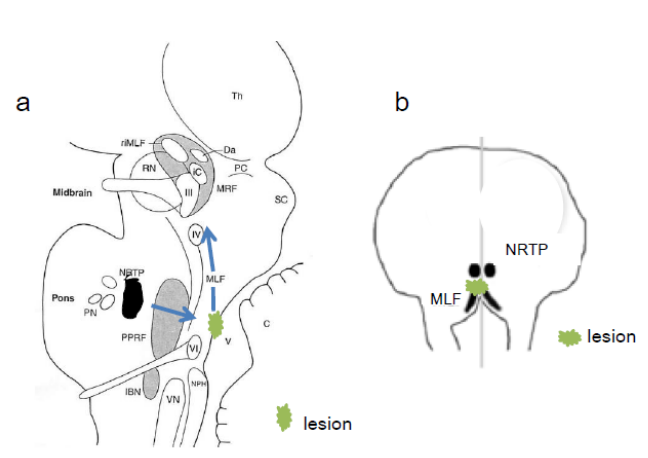

Figure 1C: a. The scheme of sagittal view of the brainstem [14] shows the mechanism of convergence impairment in pontine tegmentum. The arrows indicate the hypothetic indirect pathway from NRTP to MLF in the pontine lesion of our case. MLF, medial longitudinal fasciculus; MRF, mesencephalic reticular formation; NRTP, nucleus reticularis tegmenti pontis; PN, pontine nuclei; PPRF, paramedian pontine reticular formation; $\mathrm{V}$, fourth ventricle; III, oculomotor nucleus; IV, trochlear nucleus; VI, abducens nucleus. b. The scheme of horizontal view [15] shows the regions of NRTP and MLF, and indicated the lesion in our case.

Also, WEBINO syndrome is occurred by various causing diseases; however, multiple sclerosis or cerebral ischemic attack is much common as underlying diseases. It is important in mind to clarify the causing disease, and the appropriate and prompt therapy such as steroids or anti-platelet therapy makes a good recovery of the symptom.

In conclusion, we have reported here a case of WEBINO syndrome with convergence impairment due to a pontine infarction. The mechanism might be associated with involvement of the closed region of NRTP.

\section{References}

1. Gonyea EF (1974) Bilateral internuclear ophthalmoplegia. Association with occlusive cerebrovascular disease. Arch Neurol 31: 168-173.

2. Matsumoto H, Ohminami S, Goto J, Tsuji S (2008) Progressive supranuclear palsy with walleyed bilateral internuclear opthalmoplegia syndrome. Arch Neurol 65: 827-829.

3. Johkura K, Komiyama A, Hasegawa O (1994) Alternating exotropia associated with bilateral internuclearophthalmoplegia (WEBINO syndrome) [in Japanese] Shinkeinaika 41: 257-262.

4. Kamogawa K, Toi T, Okamoto K (2009) Case of multiple sclerosis with WEBINO syndrome [in Japanese]. Rinsho Shinkeigaku 49: 354-357.

5. Fay PM, Strominger MB (1999) Wall-eyed bilateral internuclear ophthalmoplegia in central nervous system cryptococcosis. J Neuroophthalmol 19: 131-135.

6. Inocencio FP, Ballcecer R (1985) Tuberculosis granuloma in the midbrain causing wall-eyed bilateral internuclear ophthalmoplegia (Webino). J Clin Neuroophthalmol 5: 31-35. 
Citation: Yoshinaga T, Nakamura K, Kaneko K, Nakamura A (2015) A Case Report of WEBINO Syndrome with Convergence Impairment. J Neurol Neurophysiol 6: 270. doi:10.4172/2155-9562.1000270

Page 4 of 4

7. Gonzarez-Martin Moro J, Gilo F, Rubio-Jeronimo J, Tames-Haye I (2009) Postsurgical WEBINO, a new form of this syndrome. Arch Soc Esp Opfthalmol 84: 407-410.

8. Sakamoto Y, Kimura K, Iguchi Y, Shibazaki K, Miki A (2012) A small pontine infarct on DWI as a lesion responsible for wall-eyed bilateral internuclear ophthalmoplegia syndrome. Neurol Sci 33: 121-123.

9. Kim JS, Jeong SH, Oh YM, Yang YS, Kim SY (2008) Wall-eyed bilateral internuclear ophthalmoplegia (WEBINO) from midbrain infarction. Neurology 70: e35.

10. Sierra-Hidalgo F, Moreno-Ramoas T, Villarejo A, Martin-Gil L, de Pablo-Fmandez E , et al.(2010) A variant of WEBINO syndrome after top of the basilar artery stroke. Clin Neurol Neurosurg 112: 801-804.

11. Shinoda K, Matsushita T, Furuta K, Isobe N, Yonekawa T, et al. (2011) Wall-eyed bilateral internuclear ophthalmoplegia (WEBINO). Mult Scler 17: $885-887$.
12. Chen CM, Lin SH (2007) Wall-eyed bilateral internuclear opthalmoplegia from lesions at different levels in the brainstem. J Neuroophthalmol 27: 9-15.

13. Rambold H, Sander T, Neumann G, Hemchen C (2005) Palsy of "fast" and "slow" vergence by pontine lesions. Neurology 64: 338-340.

14. Pierrot-Deseilligny C (2011) Nuclear, internuclear, and supuranuclear ocular motor disorders. In : Kennard C, Leigh RJ, eds. Handbook of Clinical Neurology, vol 102, Neuro-ophthalmology. (3rd edn), Elsevier. Amsterdam: 321.

15. Rambold H, Neumann G, Helmchen C (2004) Vergence deficits in pontine lesions Neurology 62: 1850-1853.

16. Garcia AM, Eqido JA (2013) The chameleon syndrome: acute convergence paralysis. J Neurol Neurosurg Psychiatry 84: 587. 